\title{
Triple Blind Study
}

National Cancer Institute

\section{Source}

National Cancer Institute. Triple Blind Study. NCI Thesaurus. Code C66959.

A study in which knowledge of the treatment assignments are concealed from the people who organize and analyze the data of a study as well as from subjects and investigators. 